\title{
Fit-for-Purpose Land Administration from Theory to Practice: Three Demonstrative Case Studies of Local Land Administration Initiatives in Africa
}

\author{
Uchendu Eugene Chigbu $^{1}\left(\mathbb{D}\right.$, Tobias Bendzko ${ }^{2, *}$, Menare Royal Mabakeng ${ }^{1}\left(\mathbb{D}\right.$, Elias Danyi Kuusaana ${ }^{3}$ \\ and Derek Osei Tutu 4
}

Citation: Chigbu, U.E.; Bendzko, T.; Mabakeng, M.R.; Kuusaana, E.D.; Tutu, D.O. Fit-for-Purpose Land Administration from Theory to Practice: Three Demonstrative Case Studies of Local Land Administration Initiatives in Africa. Land 2021, 10, 476. https://doi.org/10.3390/ land10050476

Academic Editors: Stig Enemark,

Robin McLaren and

Christiaan Lemmen

Received: 25 March 2021

Accepted: 28 April 2021

Published: 2 May 2021

Publisher's Note: MDPI stays neutral with regard to jurisdictional claims in published maps and institutional affiliations.

Copyright: (c) 2021 by the authors. Licensee MDPI, Basel, Switzerland. This article is an open access article distributed under the terms and conditions of the Creative Commons Attribution (CC BY) license (https:// creativecommons.org/licenses/by/ $4.0 /)$
1 Department of Land and Property Sciences, Faculty of Natural Resources and Spatial Sciences, Namibia University of Science and Technology, Windhoek 9000, Namibia; echigbu@nust.na (U.E.C.); rmabakeng@nust.na (M.R.M.)

2 Chair of Land Management, Faculty of Aerospace and Geodesy, Technical University of Munich (TUM), 80333 Munich, Germany

3 Department of Real Estate and Land Management, SD Dombo University of Business and Integrated Development Studies, Wa, Ghana; ekuusaana@uds.edu.gh

4 Lands Commission, Cantonments, Accra, Ghana; derekostus27@gmail.com

* Correspondence: tobias.bendzko@tum.de

\begin{abstract}
Land is a critical factor of production for improving the living conditions of people everywhere. The search for tools (or approaches or strategies or methods) for ensuring that land challenges are resolved in ways that quickly respond to local realities is what led to the development of the fit-for-purpose land administration. This article provides evidence that the fit-for-purpose land administration — as a land-based instrument for development-represents an unprecedented opportunity to provide tenure security in Africa. The article presents case studies from three subSaharan African countries on local-level experiences in the applications of fit-for-purpose guidelines as an enabler for engaging in tenure security generating activities in communities. These case studies, drawn from Ghana, Kenya, and Namibia, are based on hands-on local land administration projects that demonstrate how the features of the fit-for-purpose guideline were adopted. Two of the case studies are based on demonstrative projects directly conducted by the researchers (Ghana and Kenya), while the other (Namibia) is based on their engagement in an institutional project in which the Global Land Tool Network (GLTN) and other local partners were involved. This work is relevant because it paves a path for land administration practitioners to identify the core features necessary for land-based projects.
\end{abstract}

Keywords: customary tenure; fit-for-purpose; land administration; land inventory; land management; land tenure; mobile-based applications; pro-poor; land surveying; tenure security

\section{Introduction}

Access to land means gaining physical availability to land and making decisions on its use or exercise of the rights embedded therein [1,2]. Access to land is fundamental for creating livelihood opportunities for many people living in developing countries [3,4]. It is also a determinant factor on how land is put into sustainable use countries [5,6]. Important to land access, is the issue of land tenure security. It is impossible for individuals without land tenure security-i.e., the rights individuals and groups have to effective protection by the state against forced eviction-to take advantage of opportunities to improve their living standards [7-9]. Land tenure security is linked to ending poverty in all its forms everywhere. The lack of secure tenure "creates significant instabilities and inequalities in society and severely limits citizens' ability to participate in social and economic development" and "also undermines better land use and environmental stewardship and deters responsible private investment, due to the associated land risk" [10] (p. 2). The role of land tenure 
security in the socioeconomic development of nations includes ending hunger, achieving food security, and improved nutrition [11]. Others include promoting sustainable use of terrestrial ecosystems and sustainably managing forests, combating desertification, halting, and reversing land degradation in addition to halting biodiversity loss [11,12]. Unfortunately, both access to land and tenure security remain serious challenges in many parts of the world.

Land is a critical factor of production in the economies of most developing nations in Africa, Asia, and North and South America. A crucial role of the governments from these nations is the development of their land administration system (LAS) with the goal of delivering sustainable development [7]. This study focuses on African nations because they are facing challenges of all kinds that are linked to land tenure insecurity (or the lack of land tenure security) in the use of their land and natural resources. Population growth and the absence of appropriate land policy initiatives (or poor implementation of such policies where available) in Africa renders access to land unguaranteed for women, youth, and men [13-16]. Contestations in land access makes land tenure security a big concern in the continent today. This is due to pressures posed by the diverse needs (and uses) for land and unstable land tenure systems in the continent. Hence, land tenure security tops the list of the most burning social and ethical issues in Africa [17].

Intense pressures in demand for land have rendered land rights of poor and marginal groups volatile-heightening the need for their security. The poor and marginal bracket is currently youth and women that are mostly affected by land tenure insecurity $[9,16]$. Besides being excluded from critical decisions over land that has a bearing on their future legacy, they are also denied or granted limited access to land to enable them to meet their livelihood needs. The available and most recognized mechanism for accessing and securing land for all persons remains the formal or conventional land registration system [18,19]. However, the objective of land registration to deliver tenure security to all has not been realized [20]. The outcomes have not been impactful in informal urban settlements and rural areas, due to the complexities of the customary tenure, which is the most dominant tenure type in rural areas, and hybrid tenures in informal settlements countries [6]. Owing to the limited impact of formal land registration in bringing changes that benefit the poor, scholars and practitioners engaged in land administration and management are re-orienting their thoughts towards pragmatic approaches that are responsive to the local realities. Concerted efforts have been put, and remain ongoing, towards innovating or producing pro-poor and participatory approaches to achieving land tenure security in Africa. These efforts are necessary for enhancing pro-poor growth, sustainable land use, and peaceful co-existence among communities through policy development aimed at increasing land tenure security for local resource users [10,20-22]. For success to be achieved, it is important to put in place effective land administration systems (LAS) in African countries.

LAS (i.e., the way in which land tenure is conceptualized, applied, and operated) provides countries with the enabling environment for implementing land-related policies and strategies. It provides a platform for socioeconomic and environmental development. However, in most developing sub-Saharan African countries, most land parcels and the people who use them are outside of the formal LAS [10,23-25]. Most of these people outside the formal systems comprise of poor and other disadvantaged groups of people [14,20]. Several efforts to engage in locally realistic approaches to land administration (LA) have been made to ensure more locally realistic impacts in the effort to improve land access and tenure security [24-27]. These efforts have not always yielded their required results. In proposing a renewed approach to engage in tenure security improvements, Enemark et al. [10] (p. 2) noted that:

"Attempts to introduce conventional (western style) land administration solutions to close the security of tenure gap have lacked success. New innovative solutions are required to build affordable, pro-poor, scalable, and sustainable systems to identify the way all land is occupied and used. The fit-for-purpose (FFP) approach to land administration has emerged as an opportunity for developing countries in this regard. It offers a viable, 
practical solution to quickly and affordably provide security of tenure for all and to enable control of the use of all land."

This article gives credence to Enemark et al.'s [10] call to adopt locally realistic approaches for affordable, pro-poor, and sustainable solutions to land challenges in developing countries. The case studies presented in this article provide evidence that the Fit-For-Purpose land administration (FFP-LA), as a guideline for development, represents an unprecedented opportunity to provide tenure security in Africa. The article presents case studies from three sub-Saharan African countries-Kenya, Ghana, and Namibia-on local-level experiences in the guideline. The following section of the article deconstructs the key element of the FFP-LA (i.e., purpose) from the perspective of the surveying profession. It highlights the power of purpose in the LAS of developing countries and describes how the FFP-LA is a repurposing tool for enhancing land tenure security within the LAS of developing countries. This is followed by a description of the procedures for gathering and analyzing the experiences (methodology), presented in the form of case studies. Then, the discursive demonstrative case study is presented, before our conclusion.

\section{FFP-LA in Theory}

\subsection{The Power of "Purpose" in Surveying and Land-Related Professions}

Surveying or any other land-related profession aside, purpose under any situation is the dimension or the core or essence of what people do and why activities are undertaken. In life, purpose is that which provides a "profound sense of who we are, where we came from, and where we are going, the quality we choose to shape our lives around, and the source of energy and direction" [28] (p. 1). Simply put, purpose is that one element of which shapes human actions and the direction of human actions. Hence, there is power in purpose. The evolution of purpose in land-related activities is a natural one. In everyday activities, the commitment to a purpose for living requires people to ask 'Why embark on an activity? Why embark on one activity instead of the other?' In the same way, land professionals (from its earliest beginning) have always sought to answer the same question before embarking on any land-based intervention. This evolutionary trend leading towards our understanding of FFP today is best illustrated from the context of surveying. To understand what surveying is about, Bowie [29] (p. 545), over 100 years ago, explained that it is "... one of the oldest of the geophysical sciences. Originally it embraced only a limited field, consisting of the determination of the shape of the earth and its size and how this was done." Today, the subject of surveying is very closely allied with other matters beyond Bowie's [29] description of the earliest practitioners. There are various arms of surveying that exist, each designed to tackle different aspects of the needs of humanity. However, for the sake of illustrating the emergence, power, and application of purpose as an intrinsic element in the surveying profession, we focus on three key aspects of surveying (i.e., land, estate/valuation, and quantity surveying).

Surveying - a profession for surveyors-is the notable land-focused profession in all developing countries. "Surveyor", as a term, is derived from the term sur voir, which is translated to mean "overseer" [30] (p. 2). In a broad sense, surveying historically relates to the profession of overseeing land. However, the scope of the term has stretched to include specific activities related to geographic positioning, valuation, and measurement of land (including the development of land) information and the administration/management of land. Of course, we recognize that "the surveying profession may be subject to different governance structures in various jurisdictions around the world, but the responsibilities of a surveyor are reasonably consistent in most countries" [29] (p. 1). In this article, we use the land, estate/valuation, and quantity surveying to represent the three broad traditional surveying professions found in many developing countries. All these surveying professions (and others not mentioned) carry out land-related actions that are based on the responsibilities and functions meant to improve the living conditions of people in societies [31]. The land surveyor is a professional engaged in a basket of services, including cadastral and mapping services. The estate/valuation surveyor is broadly engaged in land econ- 
omy, estate management, property valuation (including plant and machinery valuation, among many other tasks), facilities management, conflict resolution, and land compensation appraisals [32]. The quantity surveyor tackles engineering estimations/costing, cost monitoring, engineering construction management, and related tasks.

Society is always the core beneficiary of the surveyors' professional actions, and therefore, purpose is central to surveying. Purpose is the working intension of surveyors. It is this intention that determines their actions. Even though their work is challenging, due to multiple tenure regimes and complex overlay of interests, surveyors strive to manage spatial needs. Their actions usually lean towards causing positive changes (or development) through activities and decisions based on functional land information infrastructure and physical land parcel management and administration systems. Land parcel management/administration roles in surveying relate to valuation, real estate, property management, and the preparation of plans or maps that represent land parcels, and to collect data [33]. These are the intensions for the purpose of land surveying. Based on a particular purpose in land surveying, different methods can apply, and various outputs. The estate/valuation surveyor engages in valuation (i.e., the assessment of property values), knowing that "the proper meaning of 'value' cannot be determined without reference to the purpose of the valuation" [34] (p. 159).

\subsection{FFP-LA Is about the "Purpose" in LA to Become Fit for Developing Countries}

As has been stressed above, surveying and all other land-related professions are purpose-driven and purpose-oriented. The need for improving land tenure security and its importance to global development is well highlighted in the Sustainable Development Goals (SDGs) [35]. The SDG-1 is focused on ending poverty in all its forms everywhere. The SDG-1 is based on a target (SDG-1.4) of ensuring that "all men and women, in particular the poor and the vulnerable, have equal rights to economic resources, as well as access to basic services, ownership and control over land and other forms of property, inheritance, natural resources, appropriate new technology, and financial services, including microfinance" by 2030. The indicator for measuring the SDG-1 is to ensure that the "proportion of total adult population with secure tenure rights to land, (a) with legally recognized documentation, and (b) who perceive their rights to land as secure, by sex and type of tenure" (SDG-1.4.2). Land tenure security is crucial for the achievement of the SDG-1 because how people and communities gain access to land and natural resources is defined and regulated by societies through land tenure systems. The role of LA is that it serves as an instrument for organizing tenure systems so that they can determine who can use what, which resources can be used, in which location the resource is located, for how long, and under which and what conditions it can be used. The procedures for achieving this vary and may largely be influenced by the sociopolitical and economic conditions of a particular country, and its colonial historical influences. That is why land tenure systems can be based on written and unwritten land policies and laws. In much of Africa, emerging characteristics of land tenure, whether secure or insecure, may be shaped by national-level legislation, customary regulations, and reforms.

Improving land tenure security in communities is a highly recognized means of reducing or alleviating poverty because it enables productive use and enjoyment, ownership, and securitization and enjoyment of land rights (including exercise of obligations, privileges, and restrictions) [36]. However, the way it has been done over the past decades is questionable. For instance, "less than a quarter of the countries in the world maintain complete LAS and about 4 billion of the world's 6 billion tenures operate outside formal governance arrangements" [37] (p. 3). To improve land tenure security in developing countries, realistic FFP-LA systems need to be established in these countries. Setting up FFP-LA systems in developing countries requires adopting a system that responds to the needs of the people and which are inclusive, equitable, efficient, sustainable, and pro-poor. Improving the land rights of the poor remains a major challenge to the industry, especially where processes and costs of LA are applied across the board for all land uses, for both urban and rural areas, 
and for all classes of persons. It also requires a change towards locally realistic and flexible approaches that can be handled within existing local-level hard and soft technologies and human resource proficiency. All of these explain why Enemark et al. [10] sought to find an approach to land interventions that is fit for purpose in tackling local land challenges in developing countries. Hence, the birth of the FFP guideline. To fully understand how the development of FFP-LA has contributed to altering the paradigm of thinking and practice in LA, it is important to revisit the meaning of land administration more vividly. This, in our view, will give a broader foundation to the proposition and application of the FFP-LA and streamline its targeting in developing countries.

LA entails "the processes of determining, recording and disseminating information about the ownership, value, and use of land when implementing land management policies" [38] (p. 108). This definition emphasized formally registered land ownership and excluded most people without land documents, such as those with customary rights, informal tenures, customary share tenants, and those with land use rights in the form of licenses. FFP-LA was developed to support access to, and the tenure security of these types of rights, but it did more than this, and has raised several questions of social exclusion and expropriation. It positively altered the how-to aspect of achieving these LA objectives, especially for many Africa countries with dominant customary land tenure and who are compelled to run parallel (hybrid) systems of LA.

The FFP-LA also has a spatial management dimension to its use, adoption, and application. The FFP-LA is based on three building blocks, including a spatial framework required to support "recording the way land is occupied and used" [10] (p. 108). The spatial frame allows for operationalizing FFP-LA to achieve pro-poor tenure security. However, this is only feasible when LA initiatives embrace the use of visible (physical) boundaries rather than fixed boundaries, aerial/satellite imagery rather than field surveys, a focus on accuracy that relates to the purpose rather than technical standards; and a demand for updating/upgrading ongoing improvements [10,22-24]. The spatial planning and management dimension of FFP-LA allows it to serve as a veritable tool in actualizing objectives of land use planning and the socioeconomic development of human settlements (urban, peri-urban, and rural). This role of FFP-LA is, however, not possible without the presence of a locally realistic spatial management system that deals with the land information and spatial data infrastructure.

FFP-LA also aligns with the idea that land rights evolve in a continuum, and an overlay of a plethora of entitlements. Continuum of land rights implies that rights to land lie along a continuum. This means that at one end of the continuum are formal land rights and at the other end of the continuum are informal rights, and between these two extremes are a wide range of other rights [39] (p. 12). The FFP-LA guideline applies in all cases (be it land titling, strengthening hybrid forms of land rights, or securing tenure under African customary laws).

It is pertinent to state that the development of FFP-LA is set in the context of the history of unrealistically exclusive western-oriented LAS in former colonies of western countries. These systems, with their associated high technology land information management systems, are not inclusive in nature. They generally exclude poor people, and regard customary tenure as retrogressive in nature. The FFP-LA is a response to finding locally realistic solutions to poor LAS in developing countries and ensure that the peculiar local needs are addressed inclusively. It is an outcome of the re-examination of the traditional land administration processes regarding their ability to support the interest of the poor in developing countries. In the words of Enemark et al. [10] (p. viii), FFP-LA is purpose-driven because:

"This new approach is focused mainly on the 'what' in terms of the outcome of security of tenure for all and, secondly, it looks at the design of 'how' this can be achieved. The 'how' should be designed to be the best 'fit' for achieving the purpose ('the what'). In this regard, the phrase 'As little as possible_as much as necessary' perfectly reflects the FFP approach." 
From the above statement, the key characteristics of FFP-LA can be described to include a focus on purpose, flexibility in land administration, responsiveness to local needs, and adoption of incremental improvements in the efforts towards improvements in land tenure security. The FFP-LA's development is one of the few innovations that has contributed to "altering the power relations and bringing about social change in parts of the global land industry; and to supporting tenure security for the poor in a number of local communities" [40] (p. 6). Its development contributes to the extension of LAS to improve the land tenure security of the poor for most people in developing countries. However, a concept cannot make a change unless it is transformed into a problem-solving tool. Hence, Enemark et al.'s transformation of the FFP-LA concept into FFP-LA guidelines [10,23,24]. This raises the question of how and where the FFP-LA guideline has been put to practice, and what impact it has made. It is essential to highlight some of these applications of the FFP-LA guideline, and to draw critical lessons for the future.

\subsection{The Features of FFP-LA}

As a concept, the FFP-LA embraces three interrelated aspects (i.e., the spatial, the legal, and the institutional frameworks) that form its practice [24]. As Enemark et al. [10]. (p. viii) clearly note:

"The spatial framework supports recording the way land is occupied and used. The scale and accuracy of this representation should be sufficient for securing the various kinds of legal rights and tenure forms recognized through the legal framework. The institutional framework is designed to manage these rights and the use of land and natural resources and to deliver inclusive and accessible services."

To ensure that the FFP-LA building blocks are well-framed to achieve their purpose for various situations, four core principles have been devised for each of its three frameworks. These principles are crucial for putting the FFP-LA guideline into practice. However, they are also embedded within the general features (that is, the attributes that make it different from other LA approaches) of the FFP-LA. To make any LA approach FFP-LA compliant, such an LA approach must adapt to all or some of these FFP-LA features. Based on Enemark et al. [10] (pp. 22-80), the features of FFP-LA which can be partially or wholly adopted in local LA interventions in any developing country include the following:

- Building the spatial framework: Availability of flexible non-statutory framework reflecting the overall spatial situation on the area under investigation.

- Visible (physical) boundaries rather than fixed boundaries: Reliance on established community or neighborhood-wide accepted physical boundaries (such as fences, ditches, hedges, seasonal and non-seasonal water bodies, and walls, etc.), rather than geodetically fixed boundaries, can provide sufficient evidence of the occupation and the attribution to tenure and land rights.

- Aerial imagery rather than field surveys: The use of a range of scales of satellite/aerial imagery as the spatial framework to identify and record visible boundaries.

- Relating accuracy to purpose rather than to technical standards: Aspiring to achieve accuracy of the land information as a relative issue related to the use of this information, rather than being driven by technical standards that are often rigid and works against the purpose for pro-poor tenure.

- Demand for updating, upgrading, and ongoing improvement: Ensuring that LA activities are not a one-off process, but rather as a process in constant flux that requires updating, upgrading, and incremental improvement whenever necessary for fulfilling land policy aims and objectives.

- Flexible framework, designed along with an administrative framework, rather than judicial lines: LA activities (such as recording and registering rights, etc.) should be based on administrative rules/regulations where and when possible, instead of legal institutions.

- Continuum of tenure rather than individual ownership: Concerning its tenure security objectives or outcome, FFP-LA embraces the continuum of land rights concept and 
practice. The continuum of land rights recognizes the existence of a diversity of tenure arrangements in practice, encompassing both legal and socially derived rights. Apart from the legal recognition of land rights, social recognition of land rights matters because it can protect the de facto land rights of local people and assign legitimacy to such rights.

- Flexible recordation rather than only one register: FFP-LA supports pro-poor land rights documentation to support the building of locally-based land recordation systems capable of serving local purposes and being able to run parallel with the national strategy or as separate activities in support of local needs.

- Gender equity for land and property rights: Irrespective of any form of progress that might have been made concerning gender issues, women's rights to land and secure tenure remain a challenge in many developing countries. The FFP-LA recognizes gender as an opportunity to create equality in the access, use, and exercise of tenure security among women, men, and youths.

- $\quad$ Building the institutional framework: Putting FFP-LA activities into practice requires a supportive institutional framework. This entails having supportive land policy, organizational structures, supportive resources, institutional networks, and institutional arrangements, organizational, among many other institutional supports.

- Good land governance rather than bureaucratic barriers: FFP-LA activities are, by way of both principle and practice, to be based on good governance. This implies embracing issues of accountability, control of corruption, political stability, and the rule of law, among many others.

- Integrated institutional framework rather than sectorial silos: In many developing countries, governments are still managing their land and natural resource assets in silos with limited interaction and coordination across sectors. FFP-LA supports coordination and collaboration across the land sectors.

- Flexible ICT approach rather than high-end technology solutions: FFP-LA recognizes the dependence on digital development as a key element in the efficient and sustainable management of land. It requires the best practices into technology-enabled activities in LA—so far, they are pro-poor and freely available for use by all.

- Transparent land information: FFP-LA encourages the provision and availability of open, transparent access to land information, subject to the protection of privacy.

In the following sections of the article, we present some case studies that highlight local-level adoptions of the FFP-LA guideline as an enabler for engaging land tenure security generating activities.

\section{Mixed Cross-Case Studies as a Research Method}

We use three demonstrative case studies to present experiential evidence that reflects on the application of FFP-LA from three regions of Africa (i.e., Eastern, Southern, and Western Africa). These case studies are drawn purposively from Ghana, Kenya, and Namibia. We use the demonstrative case study approach because it relies on presenting the situational analysis of multiple cases [40]. It is also suitable when aiming to understand the social or technical worlds of a specific development scheme using a discursive narrative to analysis. The demonstration reveals how the FFP-LA guideline was used in three case studies that involved different project arenas, land administration authorities, administrative levels, and how land administration events interact [41]. Two of the case studies are based on demonstrative projects directly conducted by the researchers (Ghana and Kenya), while the other (Namibia) is based on their engagement in an institutional project in which the Global Land Tool Network (GLTN) and other local partners were involved. We provide a precursor to the case studies below, followed by the FFP-LA focused presentations.

The Ghana case study was conducted during a two-month period, between September and November 2015. It was carried out in Juaben-Atia, a small rural community in the Juaben Municipality, one of the forty-three districts in the Ashanti Region, Ghana. The main economic activity of the populace is farming, with most of the inhabitants involved in oil 
palm plantations. Juaben-Atia lies within a customary tenure area, where the land is owned and used by local families as usufructs, while community chiefs are entrusted with allodial rights. The area has well-defined borders. This is because it benefitted from the multilateral Ghana land administration projects in 2008. During this time, its customary boundaries were demarcated as part of a piloted community mapping. However, most of the individual farm parcels were not surveyed, and individual land rights were undocumented (neither by way of informal recordation nor formal registration). The proximity of Juaben-Atia to the proposed inland port at Boankra resulted in increased land values which created a pressure of tenure insecurity within its customary land tenure systems. The need for immediate mapping and documentation of individual land rights to secure the rights of the people in the area was hindered by their inability to afford the services of professionally skilled surveyors with high-end tools. Their inability to afford such services excluded most of them, especially the poor and marginalized, from securing their land against speculators and landgrabbers. We approached the chiefs of the area to engage in a participatory land inventory, using the FFP-LA, to improve tenure security. With their permission, we engaged in piloting an inventory process in the area to explore the possibility of using standalone single frequency GPS (GNSS) receivers in smartphones and tablets to capacitate the local youths to do the mapping and documentation as a step towards securing their land. The capacity development and cost-effectiveness aspects of this case study have been reported by Osei Tutu et al. and Bendzko et al., respectively [42-44]. Our use of this case study, as is shown in the next section of this article, is to demonstrate the FFP-LA context of that exercise.

The Kenya case study was conducted in 2018 over the course of four weeks inside the Ngerenyi area in Wundanyi/Mbale in Taita, Taveta County. The entire research area covers approximately $4.7 \mathrm{~km}^{2}$ and is mostly rural. The closest city is Wundanyi Town, located $4.5 \mathrm{~km}$ away from the mountainous research area. Its high altitude is one of the main reasons for its water accessibility, due to an annual average rainfall of between 600 and $2300 \mathrm{~L}$ per $\mathrm{m}^{2}$. Most economic activities in this area are closely connected to its availability of water resources. The entire area of the Taita Hills is considered one of only five water sources in Kenya. Here we sought to understand the land tenure, land use, and tenure security issues by applying FFP-LA. Ngerenyi area was selected, due to its importance to Kenyan agriculture and dairy farming activities which yields are distributed all over the country. Tenure insecurity emerging from the use of outdated cadastral information was the main challenge in the community (worsened by increasing high land values). We engaged in a small-scale FFP-LA initiative that involved the mapping of parcels with the support of local youths in cooperation with the local Taita Taveta University. This also involved digitizing analog maps of the local mapping authorities to create a digital land information system, including up-to-date parcels and boundaries. In total, four individual teams of at least two people each were engaged in mapping the parcels and conducting the interviews in a local dialect. Although large parts of the area were mapped more than 50 years ago, only very few view updates have been added to the existing cadastral maps, due to the high cost connected. Most surveyed parcels were owned by families under customary tenure, relying on titles that were issued to deceased family members several decades ago.

The Namibian case is based on local land administration work conducted to facilitate tenure security in the Freedom Square Informal Settlements (FSIS). The researchers participated in participatory planning, data collection, and flexible surveying methods that were used over a period of eight years from 2013 to 2020 to deliver secure land rights. Gobabis is a small town in the eastern part of Namibia with an estimated population of over 20,000 in 2011 [45]. About 40\% of the population reside in informal settlements [45]. Like many other informal settlements in sub-Saharan Africa, the FSIS (being one of the six informal settlements in Gobabis, Namibia) suffers from insecure tenure. The tenure insecurity in FSIS manifested in the forms of lack of access through statutory channels, lack of documented evidence of tenure, and dependence on varieties of informal tenures. This 
means that "their occupation of land and/or housing is usually either illegal, quasi-legal, tolerated or legitimized by customary or traditional laws, which can either be recognized or simply ignored by the authorities" [46] (p. 6). The local authority initially planned to relocate the residents, as they occupied a prime piece of land planned for a formal housing project. To halt the process, community members spearheaded an enumeration and land recordation exercise. Namibia Housing Action Group (a local NGO—supporting a Shack Dwellers Federation of Namibia, a community-based organization) initiated an informal settlement profiling and enumeration process. Data on households was used to negotiate for land rights and inform in situ upgrading. A professional land surveyor surveyed the external boundaries of the settlement, while the internal subdivisions were completed by the community with a Technical Land Surveyor, according to Flexible Land Tenure System [47].

To determine how the case studies aligned with the FFP-LA guideline, we analyzed them by deconstructing the LA processes in each case study and then matched them against a matrix consisting of the FFP-LA features outlined by Enemark et al. [10]. By using these FFP-LA features to create an assessment matrix, it was possible to demonstrate an understanding of the case studies (comprising of local LA interventions) related to or adopted (or aligned to) FFP-LA.

\section{The FFP-LA in Practice: Three Demonstrative Cases Studies}

4.1. The Use of Mobile-Based Application for Youth-Led Land Inventory in Juaben-Atia, in Ghana

As part of the demonstrative FFP-LA exercise, three (3) young males from the case study area were trained to be able to assist in mapping and documenting the land rights of community members within a selected area. These trained assistants administered open and close-ended questionnaires to the 53 farmers. Collected land information data that included parcel sizes, types of interests held in land, and nature of tenure. In mapping the land parcels, the youths were led by the farmers to inspect the land parcels in the presence of a witness who, in most cases, are neighboring farmers. The farmers, in the context of Ghana's customary land tenure system, are users of land because the land is held for the community by the Chief.

Land information acquisition and storage was made using a mobile-based application which allowed for the acquisition of graphical and attributed data about all land parcels, with assurance from the local authorities that the database created can be used for land registration under proper legal provisions. The team and local technicians (youth) conducted a land survey/inventory comprised of the following equipment: A smartphone, open-source software (GIS360 and ODK Collect), laptop, portable printer, paper, ink cartridge, powerbank, and wireless GPS-device. These materials/equipment were used by the youths who participated in the exercise as para-surveyors. Table 1 illustrates the functions of these materials in the process.

This exercise demonstrates that individuals not educated in surveying can affect FFPLA if capacitated with relevant knowledge and given necessary equipment and materials. The process of conducting the land survey/inventory involved four main stages/phase of activities, including participatory enumeration, data processing, output of data, and data management. These stages represent a cyclic procedure (see Figure 1). 
Table 1. Equipment and materials for the youth-led land survey/inventory Juaben-Atia (Source: Authors'—based on materials for land use inventory exercise).

\begin{tabular}{|c|c|}
\hline Material/Equipment & Description and Use \\
\hline Smartphone/tablet & $\begin{array}{l}\text { Single handheld mobile phone and tablets with integrated GPS } \\
\text { sensors for mapping land parcels. Smartphone/tablet is also } \\
\text { used for taking photos attached to a documented evidence of } \\
\text { tenure referred to as a land passport. }\end{array}$ \\
\hline Software (GIS360 and ODK Collect) & $\begin{array}{l}\text { Open-source software Q-GIS to enable processing } \\
\text { and outputting. }\end{array}$ \\
\hline Laptop & For data storage and processing. \\
\hline Wireless GPS-Device & $\begin{array}{c}\text { For geo-tracking and georeferencing (mapping) land } \\
\text { in real-time }\end{array}$ \\
\hline Portable Printer, desk, paper, and ink cartridge & $\begin{array}{l}\text { For printing-e.g., maps on A4 sheets of paper and any } \\
\text { printable needs that may arise. }\end{array}$ \\
\hline Power-Bank/electricity & $\begin{array}{c}\text { For power storage and usage for charging smartphones } \\
\text { and laptops. }\end{array}$ \\
\hline
\end{tabular}

\section{1- Participatory}

Enumeration

Contact households and individuals to collect field and tenure related

$$
\text { data }
$$

4- Data management

Storing, use and monitoring of the land information for use - including data use and updates, linkage to formal LAS, and monitoring

\section{2- Data processing}

Assess collected data for correctness and conformity, and make corrections for locally suitable uses

\section{3- Output of data}

Using the processed data to produce tenure security generating outputs e.g. In this case, cadastral layout/inventory and "land passport"

Figure 1. The process of mobile-based application for land survey/inventory in Juaben-Atia (Source: Authors').

The four main stages of implementing FFP-LLA in a local land inventory in Ghana (Figure 1) are described below.

Participatory enumeration: This is the data capture stage. Enumeration means "to count" or "to list down" or "to ascertain the number of" [48] (p. 7). Participatory enumeration is a data-gathering process jointly conducted by the people who are being surveyed. In this case, the local youths were engaged starting from the initial consultation through other activities, such as boundary identification, and household interviews, tenure recordation, and public data verification. This stage also involved general land tenure studies about the country and the local tenure situation.

Data processing: At this stage of the exercise, we plotted the data from the field in QGIS. Where it was impossible to rectify parcel identification problems, such parcels were referred to the field technicians for re-mapping. These para-surveyors helped to map, as well as carried out data processing under our training and supervision. 
Output of data: Adopting the FFP-LA guideline led to two major outputs: Cadastral layout/inventory of parcels and the land passport (a terminology we devised to represent a parcel user or land use identification card meant as proof of use right).

Cadastral layout/inventory: The cadastral layout generated in the study comprises all the mapped parcels in the case study area. It contains spatial information on the land parcels, as well as the tenure attributes of the parcel, such as the user, the parcel size, the land use, and the land right held by the users. Each parcel was assigned a unique number that indexed it to the name and attributes of the land user. Fifty (50) mapped land parcels were generated after the data processing stage. These 50 parcels represent a total area of approximately $1.05 \mathrm{sq}$. km, and a boundary length of about $32 \mathrm{~km}$.

Land Passport and Customary Land Register: Family heads and all individuals identified as users of the land were enumerated (documented) as holders of interests in the parcel. Where all identified persons were present, they were photographed, and their photos used as evidence on the land passport. The land passport-a document received by the family head or farmer after enumeration-is a text/photo documentation of the land parcel, the land rights, and rightsholders of the parcel and signed by the relevant parties. In all cases of enumeration, the farmers using the land were members of his/her household. The land passport is a document that gives spatial information, and a profile of an individuals' and households' land rights over a parcel in writing and signed by users of neighboring parcels with a paramount chief acting as a witness. The purpose of issuing a land passport is to provide documented evidence of the households' and farmers' interests in a land parcel. Data on the land passport are extracted from the cadastral layout/inventory developed after the output of data. Information put on a land passport includes a unique parcel identifier, land-use type, location, name of the farmer, sex, age, a snapshot of photo-ID card, the right thumbprint of the farmer (family head or individual farmer where applicable), and their witness. These details form the front matter of the land passport. Although the head of households and landowners were provided with photo-ID cards, all enumerated data were stored in a customary database reflecting all identified rights in a parcel and the rightsholders and put in the custody of the Chief. To ensure that all information on the land passport and customary land register were correct, efforts were put to ensure that family members with interest on land were not excluded by ensuring that their interests are identified in the. Where only one person was met at home during the enumeration (e.g., a son), the information supplied was validated by neighbors at first, and finally by the Chief at the point of signing. This approach requires honesty on the part of participants in identifying legitimate household members. However, the Chief had the authority to request verification of data from village heads and neighboring households, before signing as a witness. Appended to the land passport is a plan of the land parcel. While not a legal document, the land passport is a paralegal certificate that can serve as evidence of ownership in the court of law in situations of dispute where none of the disputants have a full legal document to the land under contestation. Legal issues apart, it can serve as a fully recognized evidence of land use and the user within the customary governance system in which it was issued (such as in Juaben-Atia) because of the signature of the Chief as a witness on the land passport. It is enough to provide a socially recognized level of tenure security for farmers and their households at the local-level. Because it has the seal or signature of the local chief, it can deliver tenure security against unlawful eviction and entitles the occupant usufruct right to restitution/compensation under the power of an eminent domain.

Data management: In the context of this inventory exercise, this stage involved the storage and management of data. Data review and updating are crucial activities at this stage. During this stage of the land inventory, potential boundary disputes were identified and discussed to ensure they do not (re)occur or even escalate in form. Considering that we relied on general (and not fixed) boundaries in our mapping, activities in the data management stage, including updates or reviews of land information, can lead to new 
enumeration. Potentially, this stage is crucial as it may involve the (re)validation of data for linkage into the formal land registration system (in the case of a transfer or formalization.

\subsection{Land Use and Land Tenure Inventory in the Taita Hills, in Taveta Town, Kenya}

The Kenyan case study area, the Ngerenyi area, is located in Wundanyi/Mbale in Taita, Taveta County (Figure 2). The entire research area covers approximately $4.7 \mathrm{~km}^{2}$ and is mostly rural. To carry out the fieldwork, four groups of at least two trained young para-surveyors (six male and three female) were sent into the research area. The teams were selected based on their willingness to participate in the inventory exercise. The team then approached the residents who were willing to respond to the questionnaire and have their land mapped.
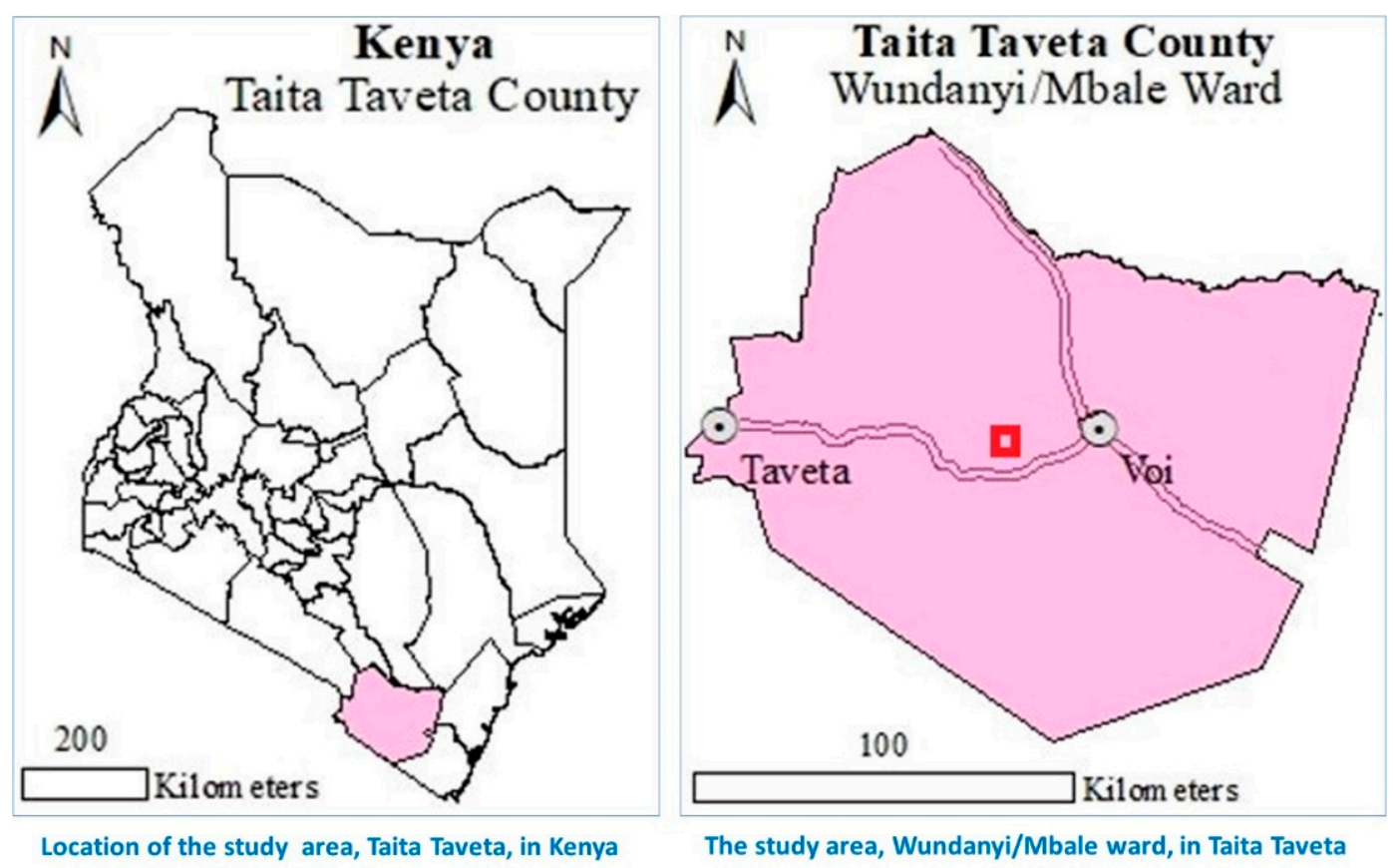

Figure 2. The location of the study area from national and local contexts (Source: Authors').

During the four weeks of data collection, the teams managed to map 347 parcels, covering large parts of the project area (Figure 3). They conducted interviews comprising to identify the users, types of tenure, incidences of tenure security, and land-uses. Following the interviews, the young para-surveyors instructed the interview partners to show the boundaries of their individual parcels.

Different from the Ghana case study, the mobile devices were equipped with the application Mapit GIS for the mapping purpose along with ODK Collect for the interviews. Daily, all collected data were gathered on one Laptop operating QGIS and creating an overarching database of all mapped parcels. After mapping each parcel, the teams were issued print-outs of the mapped parcels showing location, size, shape, name, and picture of the user of each parcel.

The same approach used in the Ghana case study was used in the Kenya case study. The equipment and materials used in Kenya were the same as those used in Ghana, except that Mapit GIS and QGIS software were combined with ODK Collect. It also followed a youth-led land survey/inventory strategy as applied in Ghana. The details of the process are as described below. 


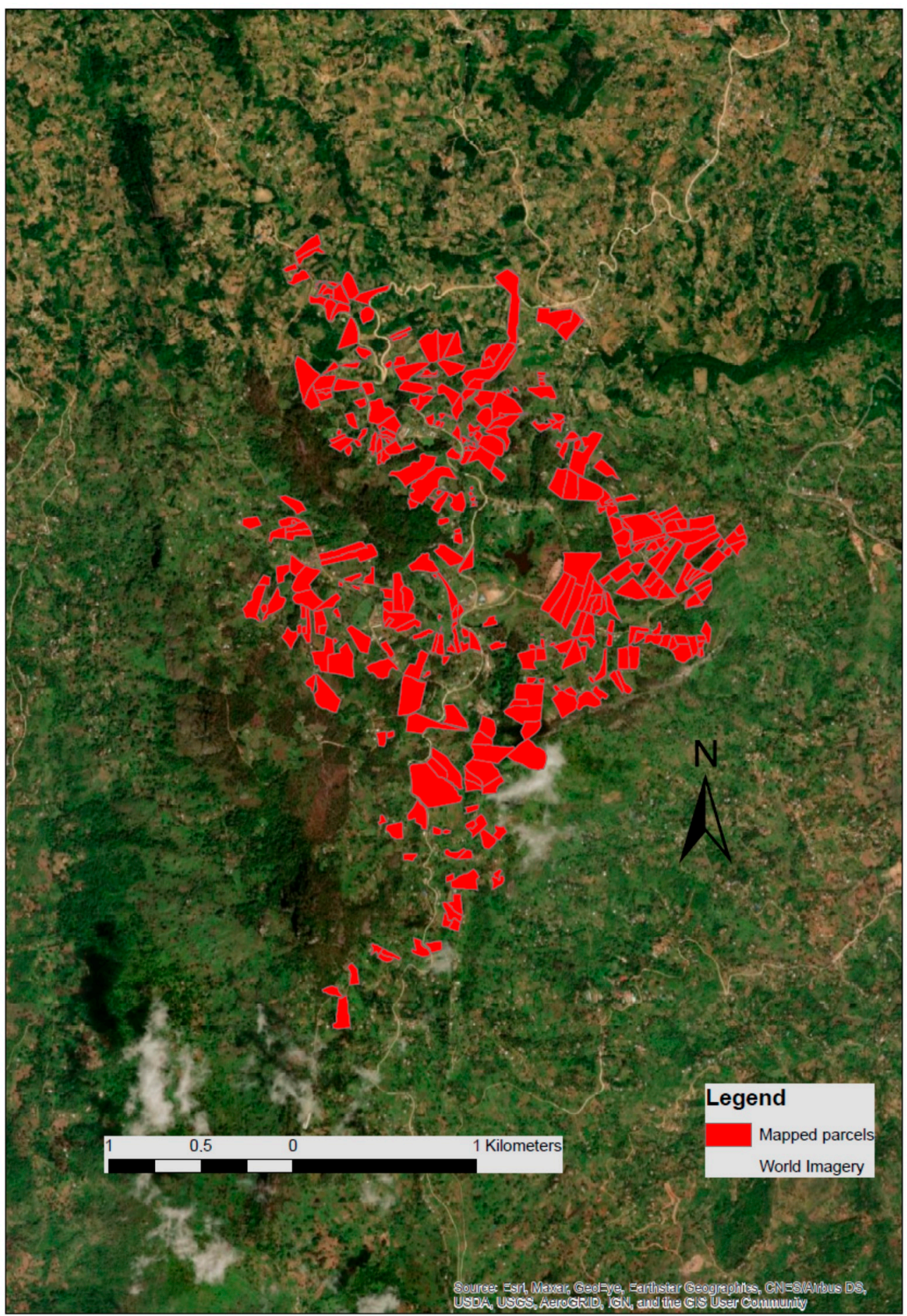

Figure 3. Mapped parcels in Ngerenyi in Wundanyi/Mbale in Taita hills, in Taveta town, Kenya (Source: Authors').

Participatory enumeration: Like the Ghana project, all participants were enumerated with each team using a specific number range of 200. Due to this unique enumeration, each mapped parcel and interview was possible to track back to the recording team and to avoid duplications of records. The enumeration process enabled a clear identification of each plot, which would not be possible with family names or other identifiers.

Data processing: After each field day, all para-surveyor teams meet for the data processing and exchange of collected data. First, the data were collected from all tablets, integrated, and merged inside QGIS. As the second step, the ODK data from the interviews 
were connected to each mapped parcel using the identifiers from the enumeration. In the final step, all teams received the current stage of mapping as an interactive map on their devices using the map import function of Mapit. During the six weeks of data collection, the para-surveyors were trained in the usage of QGIS to conduct the data processing independently. Additional to the daily data processing, conventional cadastral maps have been acquired, scanned, and digitized to receive an overview of the existing boundaries and registered plots.

Output of data: The processed data lead to three different results: The land passport for all individual users, the newly mapped cadastral inventory, and the digitized old paper-based maps from the cadastral office.

Land Passport and Customary Land Register: The land passport was documented following the same procedure as described in the case of Ghana. The procedure was replicated as stated earlier.

Cadastral Inventory: The generated land inventory comprises all the mapped parcels in the case study area, including all received data from the conducted interviews and satellite imagery helping with the general orientation. It contains spatial information on the land parcels, as well as the tenure attributes of the parcel, such as described in the land passport. Each parcel has its unique identifier can be assigned to all information collected by the questionnaires. In total, 347 individual land parcels were mapped, covering an area of about 180 ha owned by 331 different individuals.

Digitized paper-based map: In total, sixteen (16) paper-based maps of the entire area were received from the cadastral office, scanned, and brought into a digital form using rectifying tool in QGIS. For the rectifying process, at least thirty-two (32) points were georeferenced using remotely sensed images for each map to receive a highly accurate digital map for an area with very uneven terrain. The paper-based documents from the cadastral office only had very few updates and showed in all other cases the original map and boundaries from 1967.

Data management: Within the final stage of this case study and application of the FFP-LA, the results from the data processing were shared with local officials and the mapping authorities to help improve the accuracy of the current paper-based maps to the latest up-to-date technologies using GIS. To create a comprehensive digital cadastre, further efforts must be made to update the existing database and move towards a more efficient and cost-saving approach to land registration and administration. The fieldwork and the received data from the interviews showed a surprisingly high perceived tenure security which is either based on outdated documents or family graves located on the individual plots.

\subsection{Adoption of FFP-LA in Implementing the Flexible Land Tenure System in Freedom Square, Gobabis, Namibia}

The Flexible Land Tenure System (FLTS), introduced in 2012 in Namibia, offers an alternative form of tenure that addresses the core issues of imbalance and discrimination against low-income communities in Namibia. Informal settlements were envisaged to be the potential core beneficiaries of the FLTS application. The premise of establishing the FLTS is based on fit-for-purpose principles of ensuring flexibility and encouraging alternative approaches to tenure. Namibia's Flexible Land Tenure Act [49], the law that established the FLTS, was introduced with the objectives of:

- Creating alternative forms of land title that are simpler and cheaper to administer than existing forms of land title.

- Providing security of title for persons who live in informal settlements or who are provided with low-income housing.

- Empowering the persons concerned economically by means of these rights.

The tenure insecurity issues in FSIS (in Gobabis) provided a good test for the application of FLTS. About $40 \%$ of the population of Gobabis resides in informal settlements with no access to individual water connections, no toilets, while houses are mostly made 
from corrugated iron [49]. The residents have no documentation for the land they occupy. For the ten-hectare settlement, residents only had two communal water points for over 15 years. Like many informal settlements in Namibia, residents cannot invest in improving their houses, due to a lack of development rights [50] (p. 204). Residents feared eviction and were concerned about the lack of access to services. In 2012 the Gobabis Municipality shared information on a plan to relocate households from Freedom Square, as the land that was identified for formal housing. The eviction and relocation of residents from municipal land have been a normal occurrence in Gobabis, as residents have no formal rights to the land, many could not resist. However, in 2012 the community refused and proposed a better approach to avoid relocation, which will involve participatory enumerations and participatory planning [50]. They embraced these participatory approaches because of the "perceived and actual lack of land tenure security due to unclear planning regulations to citizens in the informal settlements" [51] (p. 30). The process of planning which was used in adopting FFP-LA in implementing the flexible land tenure system procedure involved the following stages.

Participatory enumerations and mapping: A team consisting of members from the community, Shack Dwellers Federation of Namibia (SDFN) representatives, with support from Namibia Housing Action Group (NHAG), started the enumeration with a two-day training exercise on enumeration and mapping. The profiling and enumerations are part of the Shack Dwellers of Namibia rituals to securing tenure and improved services for residents in informal settlements [52]. Each structure in Freedom Square was numbered and mapped using aerial images acquired from the Namibia National Planning Commission. To speed up the collection of the data, the ten-hectare settlement was divided into ten small manageable blocks [53] (p. 12).

Informal settlement data and analysis: Individual household data were collected by residents using questionnaire print-outs and aerial images. To guide the finalization of land rights registration, the project implemented in various phases used the Flexible Land Tenure Act and Regulations [54], for guidance. The legislation, which was gazetted in 2012 and regulations finalized in 2018, provided a legal framework for communities in informal settlements to access formal land rights as part of an association. Data on individual households were collected, and each structure was mapped. Data were later manually analyzed by the community using big spreadsheets. The summary data were presented to the community at various community meetings, at which the local authority representatives were present. The data were disaggregated by gender, focusing on total population, development priorities, and affordability levels of households to pay for development (land, water, and or electricity). The community analyzed the data and shared it with the local authority during a community meeting (Figure 4).

A proposal was made to re-block the settlement through participatory planning and upgrading. The participatory data collection, planning, and flexible surveying methods were used over a period of eight years from 2013 to 2020 to deliver secure land rights. Residents, mostly women and youth, were trained on mapping, enumeration, and data analysis.

Social Tenure Domain Mapping: The settlement was mapped using high resolution aerial imagery from the National Planning commission. Each structure was provided with a structure number that was later linked to the attribute data on the household. New structures not appearing on the map were drawn in with a handheld GPS. All field maps were later digitized using open-source GIS software (gvSIG software and QGIS) by students and officials of the NHAG. In 2014 there were only 700 households who resided in Freedom Square; this number increased in 2015 to 1100 households. This required an update on the initial enumerations and mapped data. STDM application was introduced to the local authority and the community representatives with support from GLTN. The purpose was to improve the data management and provision of certificates of recognition to residents, while awaiting the implementation of the FLTS [54,55]. Before the project was complete, land transactions were taking place in the settlement. Residents were transferring their shacks. A local youth was stationed at the local authority and used the data from the 
community to update the land information. Residents had to use their national identity documents to initiate a transaction. No documents were issued at this stage. The aerial images were captured using an Unmanned Aerial Vehicle (UAV), which ensured the acquisition was fast and reflected the state of the settlement [56,57]. The new settlement layout was overlaid on the images to identify households that need to be relocated.

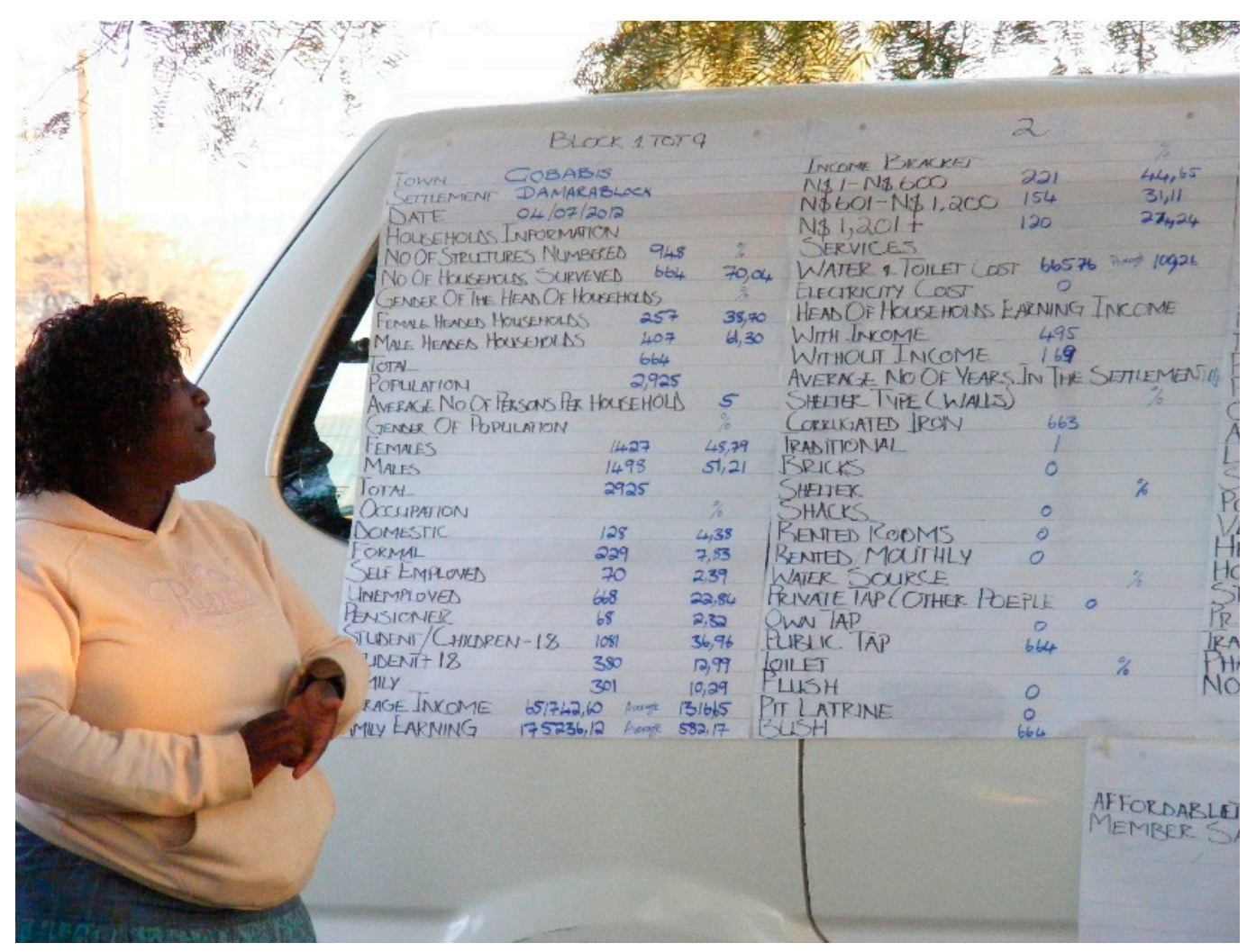

Figure 4. Community representative presenting data from enumerations (Source: Authors').

The internal boundaries in the settlement were measured by a technical land surveyor and maintained the accuracy requirements according to the Land Survey Act of the country, and the external boundaries of the settlement were surveyed by a professional land surveyor (in accordance with the high accuracy requirements under Land Survey Act 33 of 1993 of Namibia). Initial boundary recordation for Freedom Square was implemented using aerial images, and accuracy was improved upon relocation and installation of services. Implementing upgrading approaches using a continuum of accuracy would provide communities with an opportunity to complete the land inventory, and improvement can be made over time. The Flexible Land Tenure Act in Namibia provided the legal framework for using flexible approaches. The success of the project was a result of intense community participation and support from local and national government. The STDM application is ideal for communities to manage their information, however, this cannot be done in isolation. Local Authority support is ideal in this process, particularly because of their roles as a local planning authority.

Formalization: The process for secure land rights used innovative and flexible approaches, mostly with residents aiming to later construct houses [58]. The participation efforts, as part of securing tenure, are effective and can bring about results that speak to the context [59]. Residents in Gobabis started off using participatory enumerations that involved mapping, participatory planning, upgradable data collection approaches in inform the land rights registration. To proceed towards formalization, community, local authority, with the support of the Namibia University of Science and Technology, embarked on planning studios that focused on situational analysis, updating of household 
enumeration, and environmental impact assessment. The data collected was used to inform the town planning aspects of the upgrading [60]. A layout was designed by the community (see Figure 5) with guidance from spatial planners.

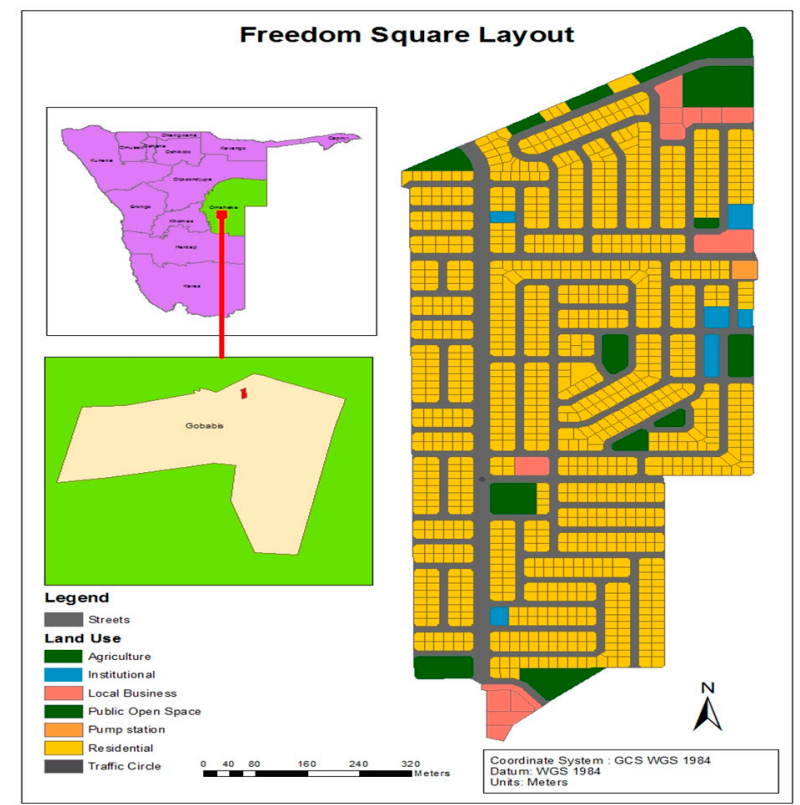

Freedom Square community layout (before)

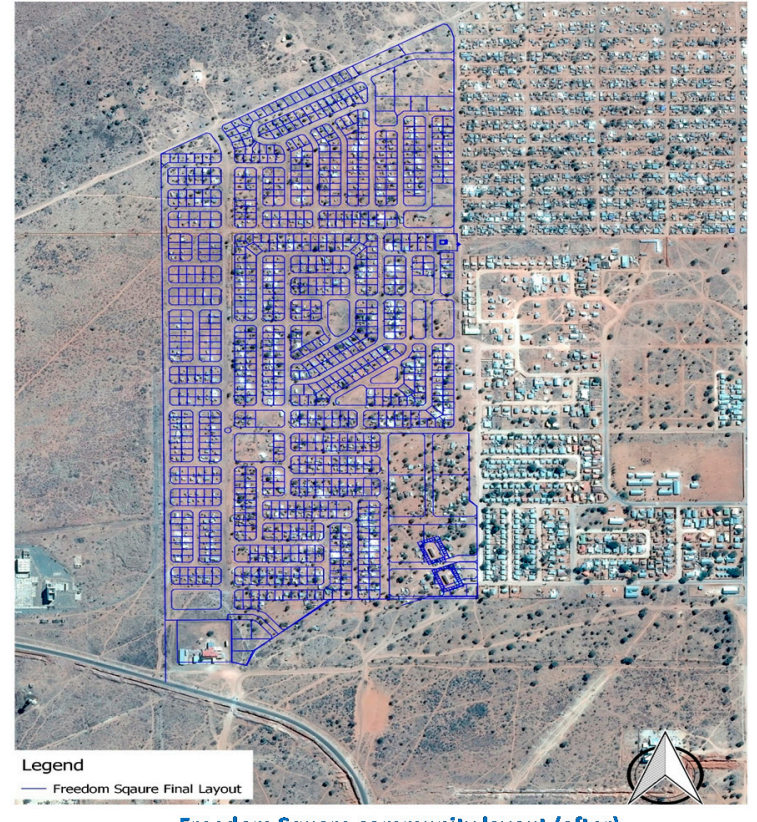

Freedom Square community layout (after)

Figure 5. Freedom Square community layout (Source: Authors').

The local authority approved the layout, and residents had to relocate within the settlement according to the layout. Public open spaces and business areas were catered for in the layout. The approved layout was overlaid on the latest imagery of the settlement and later informed the land surveying process. The survey of the settlement happened over two phases. External boundary surveys followed accuracy requirements according to the Land Survey Act 33 of 1993 [61,62]. The survey was completed by a professional land surveyor accordingly, while the internal subdivisions of the parcels followed the Flexible Land Tenure Act 4 of 2012 [47] (p. 10). The technical land surveyor applied Differential GPS (DGPS) that used the accuracy requirements according to the Land Survey Act 33 of 1993, the difference in the survey work done was the professional responsibility to complete the land survey. In the month of March 2021, some 1080 residents were presented with land hold titles through the FLT project. These land hold titles were certified by the local authorities after two years of verification of the data from the enumeration. Unlike in Ghana and Kenya, the land hold titles in Namibia are statutory documents. Owners of the land hold titles in informal settlements can exercise the right to develop their land and subdivide. Owners can also build permanent houses. The participatory enumerations led to improved tenure security for residents by firstly avoiding evictions and later accessing formal land documentation (i.e., land hold titles). Being a statutory title for informal settlers, the data from the enumeration is stored and managed by the Land Rights Office of the Ministry of Agriculture Water and Land Reform of Namibia.

\section{Discussion-Adoption of FFP-LA Features in Practice in Ghana, Kenya, Namibia, and Beyond}

A common concern in the three case studies described in this article is that they sought to secure land and property rights for people as a means for social inclusion and local economic development. A lack of access to land and insecurity of tenure epitomized a pervasive exclusion of informal settlers in FSIS (Namibia) from mainstream socioeconomic opportunities. The documentation of customary tenure to create documents in support of 
land tenure security in the social and paralegal environments was the key issue in the rural area of Ghana and Kenya. To address these problems, the FFP-LA guideline was adopted in both similar and differing ways to secure people's access to secure land. In Figure 6, we present a matrix indicating the critical features of the FFP-LA guideline that were adopted in the three case studies.

\begin{tabular}{|c|c|c|c|c|}
\hline \multicolumn{2}{|c|}{$\begin{array}{l}\text { Adoptable FFP-LA } \\
\text { features }\end{array}$} & $\begin{array}{l}\text { Ghana } \\
\text { (Rural) }\end{array}$ & $\begin{array}{c}\text { Kenya } \\
\text { (Peri-urban) }\end{array}$ & $\begin{array}{l}\text { Namibia } \\
\text { (Urban) }\end{array}$ \\
\hline \multicolumn{2}{|c|}{$\begin{array}{l}\text { A spatial development } \\
\text { framework (SDF) }\end{array}$} & $\begin{array}{l}\text { Ghana has SDF upon } \\
\text { which all LA are based }\end{array}$ & $\begin{array}{l}\text { No SDF upon which all LA } \\
\text { are based in Kenya }\end{array}$ & $\begin{array}{l}\text { FLTS served as spatial } \\
\text { framework }\end{array}$ \\
\hline \multicolumn{2}{|c|}{$\begin{array}{l}\text { Visible (physical) rather } \\
\text { than fixed boundaries }\end{array}$} & $\begin{array}{l}\text { Natural features (trees) } \\
\text { used as boundary marks }\end{array}$ & $\begin{array}{l}\text { Natural features (trees) } \\
\text { used as boundary marks }\end{array}$ & $\begin{array}{l}\text { Fixed boundaries was } \\
\text { used }\end{array}$ \\
\hline \multicolumn{2}{|c|}{$\begin{array}{l}\text { Aerial imagery rather than } \\
\text { field surveys }\end{array}$} & $\begin{array}{l}\text { Both aerial images \& field } \\
\text { surveys were used }\end{array}$ & $\begin{array}{l}\text { Both aerial images \& field } \\
\text { surveys were used }\end{array}$ & $\begin{array}{l}\text { Aerial imagery and field } \\
\text { survey used }\end{array}$ \\
\hline \multicolumn{2}{|c|}{$\begin{array}{l}\text { Accuracy of purpose rather } \\
\text { than technical standards }\end{array}$} & $\begin{array}{l}\text { Tenure security as } \\
\text { purpose. Neighbors } \\
\text { served as witnesses }\end{array}$ & $\begin{array}{l}\text { Tenure security as } \\
\text { purpose. Neighbors } \\
\text { served as witnesses }\end{array}$ & $\begin{array}{l}\text { Tenure security as } \\
\text { purpose. Community } \\
\text { members as witnesses }\end{array}$ \\
\hline \multicolumn{2}{|c|}{$\begin{array}{l}\text { Updating, upgrading and } \\
\text { ongoing improvement }\end{array}$} & $\begin{array}{l}\text { Update \& upgrading via } \\
\text { land rights continuum }\end{array}$ & $\begin{array}{l}\text { Update \& upgrading via } \\
\text { land rights continuum }\end{array}$ & $\begin{array}{l}\text { Update \& upgrading via } \\
\text { land rights continuum }\end{array}$ \\
\hline \multicolumn{2}{|c|}{$\begin{array}{l}\text { Legal and regulatory } \\
\text { framework (L\&R) }\end{array}$} & $\begin{array}{l}\text { L\&R allow for statutory \& } \\
\text { customary land tenure }\end{array}$ & $\begin{array}{l}\text { L\&R allow for statutory \& } \\
\text { customary land tenure }\end{array}$ & $\begin{array}{l}\text { L\&R allow for social \& } \\
\text { statutory land tenure }\end{array}$ \\
\hline \multicolumn{2}{|c|}{$\begin{array}{l}\text { Flexibility in administrative } \\
\text { rather than judicial lines }\end{array}$} & $\begin{array}{l}\text { Land administration via } \\
\text { chiefs is flexible \& rigid }\end{array}$ & $\begin{array}{l}\text { Administrative flexibility } \\
\text { improvised, but on-the- } \\
\text { ground structure inflexible }\end{array}$ & $\begin{array}{l}\text { FLTS is designed to } \\
\text { provide flexibility in LAS }\end{array}$ \\
\hline \multicolumn{2}{|c|}{$\begin{array}{l}\text { Continuum of tenure rather } \\
\text { than ownership }\end{array}$} & $\begin{array}{l}\text { Focused on ownership \& } \\
\text { subsidiary land rights }\end{array}$ & $\begin{array}{l}\text { Focused on ownership \& } \\
\text { subsidiary land rights }\end{array}$ & $\begin{array}{l}\text { Focused on ownership } \\
\& \text { subsidiary land rights }\end{array}$ \\
\hline \multicolumn{2}{|c|}{$\begin{array}{l}\text { Flexible recordation rather } \\
\text { than only one register }\end{array}$} & $\begin{array}{l}\text { Created a customary } \\
\text { land register }\end{array}$ & Created a land register & $\begin{array}{l}\text { Created social tenure } \\
\text { register }\end{array}$ \\
\hline \multicolumn{2}{|c|}{$\begin{array}{l}\text { Gender equity for land and } \\
\text { property rights }\end{array}$} & $\begin{array}{l}\text { Youth engagement } \\
\text { irrespective of gender }\end{array}$ & $\begin{array}{l}\text { Youth engagement } \\
\text { irrespective of gender }\end{array}$ & $\begin{array}{l}\text { Women engagement } \\
\text { based on inclusiveness }\end{array}$ \\
\hline \multicolumn{2}{|c|}{$\begin{array}{l}\text { Building the institutional } \\
\text { framework }\end{array}$} & $\begin{array}{l}\text { Emphasized both social } \\
\text { and statutory tenure }\end{array}$ & $\begin{array}{l}\text { Emphasized both social } \\
\text { and statutory tenure }\end{array}$ & $\begin{array}{l}\text { Emphasized both social } \\
\text { and statutory tenure }\end{array}$ \\
\hline \multicolumn{2}{|c|}{$\begin{array}{l}\text { Good land governance } \\
\text { rather than bureaucracy }\end{array}$} & $\begin{array}{l}\text { Bureaucracy reduced, } \\
\text { but not avoided. chiefs } \\
\text { follow customary rites }\end{array}$ & $\begin{array}{l}\text { Bureaucracy reduced, } \\
\text { but not avoided. chiefs } \\
\text { follow customary rites }\end{array}$ & $\begin{array}{l}\text { Highly bureaucracy due } \\
\text { to statutory demands }\end{array}$ \\
\hline \multicolumn{2}{|c|}{$\begin{array}{l}\text { Institutional integrations } \\
\text { rather than sectorial silos }\end{array}$} & $\begin{array}{l}\text { Created database not } \\
\text { linked to formal register }\end{array}$ & $\begin{array}{l}\text { Created database not } \\
\text { linked to formal register }\end{array}$ & $\begin{array}{l}\text { Created database linked } \\
\text { to statutory register }\end{array}$ \\
\hline \multicolumn{2}{|c|}{$\begin{array}{l}\text { Flexible ICT rather than } \\
\text { high-end technology }\end{array}$} & $\begin{array}{l}\text { Use of standalone single } \\
\text { frequency GPS (GNSS) } \\
\text { receiver in smartphones }\end{array}$ & $\begin{array}{l}\text { Use of standalone single } \\
\text { frequency GPS (GNSS) } \\
\text { receiver in smartphones }\end{array}$ & STDM \\
\hline Legend & Fully adop & Modera & dopted & Not adopted \\
\hline
\end{tabular}

Figure 6. Matrix of case studies' adoption of the FFP-LA features (Source: Authors').

Figure 6 is a matrix showing the adoption of FFP-LA features. In the matrix, the green, blue, and yellow shades represent the qualitative extent of FFP-LA adoption in the case studies. Green represents fully adopted, blue entails moderately adopted, and yellow indicates not adopted. Focusing on the case study matrix, we discuss the what and how in relation to the adoption of the FFP-LA features identified by Enemark et al. [10]. These features were adopted at the local-level in the case studies in Ghana, Kenya, and Namibia, as described below.

- Building the spatial framework: Availability of a spatial development framework is crucial for ensuring a flexible non-statutory framework. The approaches used in Ghana depended on the existing SDF. Ghana has a national SDF [63], while Namibia and Kenya do not have any SDF.

- Visible (physical) rather than fixed boundaries: The Ghanaian and Kenyan case studies relied on natural landmarks as physical boundaries (e.g., fences, trees, ditches, hedges, seasonal and non-seasonal water bodies, and walls), rather than geodetically fixed boundaries. In Namibia, due to the statutory interest in the FLTS, it was essential to use fixed boundaries. External boundaries of blocks of parcels are fixed in the 
Namibian case. The internal boundaries are also fixed; however, they are usually less accurate as they were done by technicians or para-surveyors.

- Aerial imagery rather than field surveys: In all cases, both aerial images were complemented with field surveys to collect data and map land parcels. Aerial images from the local authority helped in identifying and recording visible boundaries.

- Accuracy in relation to the purpose rather than technical standards: In all three cases, land tenure security was a core purpose. Pursuing technical accuracy was considered less important to achieving the purpose (i.e., tenure security).

- Updating, upgrading, and ongoing improvement: With a focus fixed on purpose rather than standards, all cases ensured that the LA activities were viewed as a continuum only efficient through regular updates and improvements, rather than a one-off process. For instance, although the FSIS in Gobabis ended in 2018, it evolved into the title to the land for some residents in early 2021. The continuum of land rights was the core principle for the enumerations and inventories. This allowed for updating and upgrading.

- Legal and regulatory framework: In all cases, there are legal and regulatory frameworks for FFP-LA. In Namibia, the FLTS is well designed for an FFP approach. In Ghana and Kenya, the land policies (including the statutory recognition of customary land tenure) provide a legal/regulatory framework for tenure security improvement as applied in these projects.

- Flexibility in administrative rather than judicial lines: The methods (e.g., land tenure enumeration and use of STDM) and the not-so-technical materials used in the land use inventories allowed for flexibility. The customary governance (in Ghana) and the commitment of the county administration (in Kenya) allowed for flexibility on the projects. The informal governance in FSIS (in Namibia) allowed for greater flexibility. The need to follow administrative rules/regulations (rather than legal institutions), as in the case of Namibia, is crucial because it helped to lay a foundation for social legitimacy in implementing FFP-LA. And this is because the participatory enumerations took place before the FLTS regulations were passed. Apart from the ease or flexibility of implementing the land-based activities, it also allowed the communities to own the process and be accountable for its success or failures. Administrative practice allows for social legitimacy or formalities, while legal frameworks help to ensure adherence to legislation.

- Continuum of tenure rather than ownership: In Namibia, the FLTS is a manifestation of Namibia's adherence to the continuum principle in land rights. In all cases, the approaches recognized the existence of a possibility of various tenure arrangements within the project areas. Property rights were envisaged beyond ownership.

- Flexible recordation rather than only one register: The three case studies involved flexible and pro-poor land rights documentation based on partnerships with government and local people (the youths in Ghana and Kenya, and women in Namibia). It also involved the use of easily accessible and usable land recordation systems (or equipment) capable of serving local purposes and being operated by local people.

- Gender equity for land and property rights: Focus on participation was put on the equal participation of men and women in Ghana and Kenya. This allowed for learning and equal capacity building for both men and women. In Namibia, the FSIS used enumerators who identified as female. This allowed for the inclusion of female voices, which may otherwise have been suppressed in the Namibian social context. The STDM was also used to capture and store gender (male and female only) disaggregated data for gender-responsive decisions in the informal settlements.

- Building the institutional framework: The three cases led to the development and the testing of new rules of tenure application (i.e., establishment of new land information systems for local LAS applications). They emphasized both social and statutory tenure and procedures for future tenure improvement processes by setting a platform for upgrading and updating the new LAS. 
- Good land governance rather than bureaucracy: All three cases are based on appropriate governance, which is not perfectly good in the sense of good land governance. In the rural and peri-urban areas of Ghana and Kenya, respectively, reliance on chiefs and local authorities is still bureaucratic. In the informal settlements (Namibia), dependence on the FLTS was highly bureaucratic, due to the statutory requirements for issuing land hold titles.

- Institutional integrations rather than sectorial silos: The Kenyan and Ghanaian case studies involved the potential sector integration between customary and statutory tenure. The Namibian case is a complete integration of the formal and informal urban land sectors.

- Flexible ICT rather than high-end technology: In all cases, the governance approach and equipment used to allow for open and transparent access to land information.

Considering how these FFP-LA procedures took place in the three case studies, this study has broader implications elsewhere in other sub-Saharan countries and the global south. Lessons from these case studies indicate that the FFP-LA is not limitable by geography. Its purpose, flexibility of its engagement, and pro-poor expectations from its outcomes are the core determinants of the feasibility or viability of its adoption anywhere. This means that the different (yet highly similar) procedures followed in the three cases (Ghana, Kenya, and Namibia) can also be in other countries, such as India, Indonesia, or Fiji, if their context is similar. Such similarity may relate to situations where the purpose, procedure, and expected outcome are relatable.

\section{Conclusions}

These case studies demonstrate that adopting FFP approaches in local LAS is possible in different spatial contexts. They show that FFP-LA supports pro-poor land interventions. The cases support the understanding that securing tenure does not require accurate surveys [25] (p. 19). They also indicate that FFP-LA improves tenure security (important measures for achieving SDGs 1, 2, 5, 11, and 15) which are of crucial importance to Africa's development [35]. Cognizance of the technical nature of surveying, this article demonstrates that using a mobile application (that operates on a single frequency GPS) by trained local people (especially youths and women) enables mapping exercises that minimize cost and still enhance the land tenure security of people. All three case studies demonstrate the paradigm shift in LA which emerged because of the FFP-LA guideline and practice. Alignment towards pro-poor approaches as a means of securing land rights within a continuum concept, especially in rural (Ghana), peri-urban (Kenya), and informal urban settlements (Namibia) in Africa, is demonstrated. The study represented three simple, locally-adopted, and innovative approaches that focused on local experiences and allowed the local people to play critical roles in the process.

The application of the guideline of FFP-LA in Namibia provides an opportunity about how to secure tenure in informal urban settlements at scale and ensure improved living conditions for occupants in areas formerly under tenure insecurity. The case studies of Ghana and Kenya, though not at scale, reflect an example of how the FFP-LA can be adopted in rural and peri-urban areas, respectively. Securing land rights for informal settlement residents in Juaben-Atia (Ghana) and Taita Hills (Kenya) and FSIS in Gobabis (Namibia) relied on features of FFP-LA. Each aspect of the FFP implementation involved flexible, inclusive, participatory, affordable, reliable, attainable, and upgradable measures that fit in the local legal, spatial, and institutional frameworks [22] (p. 17). Moreover, the respective communities led the process to secure the tenure through land rights documentation and titling for over 1000 households in Gobabis Namibia. The Gobabis case study is noteworthy because its tenure documentation has evolved beyond the local (alternative documentation) into statutory land titles. In March 2021, households in FSIS became beneficiaries of land holding titles, under the Flexible Land Tenure Act 4 of 2012) [46]. This final recognition of land rights took more than five years to materialize. However, unlike the cases of JuabenAtia (Ghana) and Taita Hills (Kenya), it demonstrates that FFP-LA techniques can do more 
than provide paralegal protection. It can lead to full tenure security if the processes are well managed, and participatory approaches are center stage.

It is essential to note (or rather reiterate) that this study is a demonstrative one. It has been conceived to show that FFP-LA as a concept can be applied in different forms, depending on where and how it is implemented. It confirms that FFP-LA outcomes should be done within an enabling environment that respects "administrative structures, policy frameworks, institutional and social settings, collective actions, and social learning" [64] (p. 12). To what degree it is adopted based on established principles. While the demonstrative case studies (i.e., evidence presented with a focus on procedures) are crucial for grasping how to adopt and implement FFP-LA in African countries, there is still a need to engage in research to provide substantive evidence to help land administrators resolve LA challenges relate to the performance of specific steps in the FFP-LA. This will enable land administrators to understand the impact and consequences of each of the steps (and principles of the FFP-LA).

Author Contributions: Conceptualization, U.E.C.; methodology, U.E.C., M.R.M., T.B., E.D.K., D.O.T.; validation U.E.C., M.R.M., T.B., E.D.K., D.O.T.; formal analysis, U.E.C., M.R.M., T.B., E.D.K., D.O.T.; investigation, U.E.C., M.R.M., T.B., E.D.K., D.O.T.; resources, U.E.C., M.R.M., T.B., E.D.K., D.O.T.; data curation, U.E.C., M.R.M., T.B., D.O.T.; writing-original draft preparation, U.E.C., M.R.M., T.B., E.D.K., D.O.T.; writing-review and editing, U.E.C., M.R.M., T.B., E.D.K., D.O.T.; visualization, U.E.C., M.R.M., T.B.; supervision, U.E.C. All authors have read and agreed to the published version of the manuscript.

Funding: This research received no external funding. The APC was funded by the German Research Foundation (DFG) and the Technical University of Munich (TUM) in the framework of the Open Access Publishing Program.

Institutional Review Board Statement: Not applicable.

Informed Consent Statement: Not applicable.

Data Availability Statement: Not applicable.

Acknowledgments: Acknowledgment is given to the Global Land Tool Network (GLTN), especially its Research and training cluster, for facilitating the study. The GLTN supported the Ghana and Namibia case studies. The DAAD (German Academic Exchange Service) supported the Kenyan case study. The article was prepared under the auspices of a research collaboration between the Namibia University of Science and Technology (Namibia), SD Dombo University of Business and Integrated Development Studies, Wa (Ghana), Technical University of Munich (Germany), and the Ghana Lands Commission.

Conflicts of Interest: The authors declare no conflict of interest.

\section{References}

1. Bendzko, T.; Chigbu, U.E.; Schopf, A.; de Vries, W.T. Consequences of land tenure on biodiversity in arabuko sokoke forest reserve in Kenya: Towards responsible land management outcomes. In Agriculture and Ecosystem Resilience in Sub Saharan Africa; Bamutaze, Y., Kyamanywa, S., Singh, B., Nabanoga, G., Lal, R., Eds.; Springer: Cham, Switzerland, 2019.

2. Chigbu, U.E. Masculinity, men and patriarchal issues aside: How do women's actions impede women's access to land? Matters arising from a peri-rural community in Nigeria. Land Use Policy 2019, 81, 39-48. [CrossRef]

3. Toulmin, C. Securing land and property rights in sub-Saharan Africa: The role of local institutions. Land Use Policy 2009, 26, 10-19. [CrossRef]

4. Gwaleba, J.M.; Chigbu, U.E. Participation in property formation: Insights from land-use planning in an informal urban set-tlement in Tanzania. Land Use Policy 2020, 92, 104482. [CrossRef]

5. Mas, J.-F. Monitoring land-cover changes: A comparison of change detection techniques. Int. J. Remote Sens. 1999, 20, 139-152. [CrossRef]

6. Owusu Ansah, B.; Chigbu, U.E. The nexus between peri-urban transformation and customary land rightsdisputes: Effects on peri-urban development in Trede, Ghana. Land 2020, 9, 187. [CrossRef]

7. United Nations Human Settlement Programme. Secure Land Rights for All; GLTN/UN-Habitat: Nairobi, Kenya, 2008.

8. Handayani, W.; Chigbu, U.E.; Rudiarto, I.; Putri, I.H.S. Urbanization and Increasing Flood Risk in the Northern Coast of Central Java-Indonesia: An Assessment towards Better Land Use Policy and Flood Management. Land 2020, 9, 343. [CrossRef] 
9. Chigbu, U.E. Land, Women, Youths, and Land Tools or Methods: Emerging Lessons for Governance and Policy. Land 2020, 9, 507. [CrossRef]

10. Enemark, S.; McLaren, R.; Lemmen, C. Fit-for-Purpose Land Administration Guiding Principles for Country Implementation; UN Habitat: Nairobi, Kenya, 2016.

11. Gaafar, R. Women's Land and Property Rights in Kenya. Center for Women's Land Rights; Centre for Women's Land Rights-Landesa: Seattle, WA, USA, 2014.

12. Dachaga, W.; Chigbu, U.E. Understanding tenure security dynamics in resettlement towns: Evidence from the Bui Resettlement Project in Ghana. J. Plan. Land Manag. 2020, 1, 38-49. [CrossRef]

13. Catioiti, A. Land Issue, a Challenge to the Social Mission of the Church: A Theological Socio-Cultural Study on Kenya Land Tenure; Tangaza University College: Nairobi, Kenya, 1999.

14. Ntihinyurwa, P.D.; de Vries, W.T.; Chigbu, U.E.; Dukwiyimpuhwe, P.A. The positive impacts of farm land fragmentation in Rwanda. Land Use Policy 2019, 81, 565-581. [CrossRef]

15. de Vries, W.; Chigbu, U.E. Responsible Land Management-Concept and application in a territorial rural context. Fub-Flächenmanag. Bodenordn. 2017, 79, 65-73.

16. Kidido, J.K.; Bugri, J.T.; Kasanga, R.K. Dynamics of Youth Access to Agricultural Land under the Customary Tenure Regime in the Techiman Traditional Area of Ghana. Land Use Policy 2017, 60, 254-266. [CrossRef]

17. Mkuzi, T.H. Assessment of Land Tenure, Land Use and Land Cover Changes in Taita Hills Forest Fragments: A Case Study of Ngerenyi Forest Fragments in Taita Taveta County, Kenya. Master's Thesis, Pwani University, Kilifi, Kenya, 2020.

18. Ubink, J.M.; Hoekema, A.J.; Assies, W.J. Legalising Land Rights: Local Practices, State Responses and Tenure Security in Africa, Asia and Latin America; Leiden University Press: Leiden, The Netherlands, 2009; p. 618.

19. Chigbu, U.E.; Schopf, A.; De Vries, W.T.; Masum, F.; Mabikke, S.; Antonio, D.; Espinoza, J. Combining land-use planning and tenure security: A tenure responsive land-use planning approach for developing countries. J. Environ. Plan. Manag. 2016, 60, 1622-1639. [CrossRef]

20. Quan, J. Lessons learnt in land policy and land administration. Presented at the World Bank Electronic Conference, Online.

21. Zevenbergen, J.; Augustinus, C.; Antonio, D.; Bennett, R. Pro-poor land administration: Principles for recording the land rights of the underrepresented. Land Use Policy 2013, 31, 595-604. [CrossRef]

22. Enemark, S.; Hvingel, L.; Galland, D. Land administration, planning and human rights. Plan. Theory 2014, 13, 331-348. [CrossRef]

23. Enemark, S. Fit-for purpose Land Administration. GIM Int. 2013, 27, 26-29.

24. Enemark, S.; Bell, K.C.; Lemmen, C.H.; McLaren, R. Fit-for-Purpose Land Administration; International Federation of Surveyors (FIG): Copenhagen, Denmark, 2014.

25. Ameyaw, P.D.; Dachaga, W.; Chigbu, U.E.; De Vries, W.T.; Abedi, L. Responsible Land Management: The Basis for Evaluating Customary Land Management in Dormaa Ahenkro, in Ghana. In Proceedings of the World Bank Conference on Land and Poverty, Washington, DC, USA, 19-23 March 2018; pp. 1-18.

26. Antonio, D.; Mabikke, S.; Selebalo, C.; Chigbu, U.E.; Espinoza, J. Securing Tenure through Responsive Land Use Planning: An Innovative Tool for Country Level Interventions. In Proceedings of the FIG Working Week Christchurch, Christchurch, New Zealand, 2-6 May 2016.

27. Masum, F.; Chigbu, U.E.; Espinoza, J.; Graefen, C. The limitations of formal land delivery system: Need for a pro-poor urban land development policy in dhaka, bangladesh. In Proceedings of the World Bank Conference on Land and Poverty, Washington, DC, USA, 14-18 March 2016.

28. Leider, R.J. The Power of Purpose: Creating Meaning in Your Life and Work; Berrett-Koehler: San Francisco, CA, USA, 2004.

29. Bowie, W. Present status of geodesy and some of the problems of this branch of geophysics. In Proceedings of the First Annual Meeting of the American Geophysical Union, Washington, DC, USA, 23 April 1920.

30. Allred, G.K. The surveying profession. In Proceedings of the 6th FIG Regional Conference, Coastal Areas and Land Administration-Building the Capacity, San José, Costa Rica, 12-15 November 2007.

31. Allred, G.K. The Land Surveyor as a Public Officer. In Proceedings of the XX Congress of the Fédération Internationale des Géomètres, Surveying global changes, Melbourne, Australia, 5-12 March 1994.

32. Chigbu, U.E. Land tenure security in Nigeria. In Land Tenure Security in Selected Countries: Global Report; Kirk, M., Mabikke, S., Antonio, D., Chigbu, U.E., Espinoza, J., Eds.; UN-Habitat: Nairobi, Kenya, 2015; pp. 62-86.

33. Minchin, M. Introduction to Surveying. Government of Western Australia; Department of Training and Workforce Development: West Perth, Australia, 2016.

34. Nerlove, S.H. “Valuation of Property": A Review. Univ. Chic. Law Rev. 1939, 6, 157. [CrossRef]

35. United Nations. The Sustainable Development Goals Report; United Nations Organisation: New York, NY, USA, 2016.

36. Chigbu, U.E.; Ntihinyurwa, P.D.; de Vries, W.T.; Ngenzi, E.I. Why tenure responsive land-use planning matters: Insights for land use consolidation for food security in Rwanda. Int. J. Environ. Res. Public Health 2019, 16, 1354. [CrossRef]

37. Zevenbergen, J.; De Vries, W.T.; Bennett, R. (Eds.) Advances in Responsible Land Administration; CRC Press: New York, NY, USA, 2016; ISBN 978-4987-1959-9.

38. United Nations Economic Commission for Europe-UNECE. Land Administration Guidelines with Reference to Countries in Transition; United Nations: New York, NY, USA, 1996. 
39. UN-Habitat; Global Land Tool Network (GLTN); International Institute for Rural Reconstruction (IIRR). Handling Land, Innovative Tools for Land Governance and Secure Tenure; UNON: Nairobi, Kenya, 2012.

40. Augustinus, C. Catalysing global and local social change in the land sector through technical innovation by the United Nations and the Global Land Tool Network. Land Use Policy 2020, 99, 105073. [CrossRef]

41. Vinge, H. Farmland conversion to fight climate change? Resource hierarchies, discursive power and ulterior motives in land use politics. J. Rural. Stud. 2018, 64, 20-27. [CrossRef]

42. De Vries, W.T. The influence and relevance of social values and believe systems in land readjustment processes. In Proceedings of the International Conference on Real Estate Development and Management ( ICREDM 2020), Ankara, Turkey, 30 January-2 February 2020.

43. Osei Tutu, D.; Asante, L.A.; Appiah, M.N.; Bendzko, T.; Chigbu, U.E. Towards a pro-poor customary land rights security in rural Ghana: Land tenure inventory using mobile application by local youth. In Proceedings of the World Bank Conference on Land and Poverty, Washington, DC, USA, 14-18 March 2016.

44. Bendzko, T.; Ameyaw, P.D.; Chigbu, U.E.; de Vries, W.T.; Osei Tutu, D. Embracing the rubber-boot approach to securing customary land rights with focus on low-cost land-use inventory. In Proceedings of the World Bank Conference on Land and Poverty, Washington, DC, USA, 20-24 March 2017.

45. Namibia Statistics Agency (NSA). Namibia 2011 Population \& Housing Census-Main Report; NSA: Windhoek, Namibia, 2013.

46. Payne, G.; Durand-Lasserve, A.; Geoffrey Payne \& Associates. Holding on: Security of Tenure-Types, Policies, Practices and Challenges. Research Paper Prepared for the Expert Group Meeting on Security of Tenure Convened by the Special Rapporteur. 2012, pp. 22-23. Available online: http://www.ohchr.org/Documents/Issues/Housing/SecurityTenure/PayneDurand-Lasserve-BackgroundPaper-JAN2013.pdf (accessed on 19 March 2021).

47. Republic of Namibia. Flexible Land Tenure Act of 2012. Government Gazette, 13 June 2012.

48. Global Land Tool Network. Count Me in: Surveying for Tenure Security and Urban Land Management; GLTN/UN-Habitat: Nairobi, Kenya, 2010.

49. Weber, B.; Mendelsohn, J. Informal Settlements in Namibia: Their Nature And Growth; Development Workshop Namibia: Namibia, Africa, 2017. Available online: https://www.researchgate.net/publication/322200418_Informal_settlements_in_Namibia_their_ nature_and_growth (accessed on 14 March 2021).

50. Lankhorst, M. Land Tenure Reform and tenure Secuirty in Namibia. In Legalising Land Rights Local Practices, State Responses and Tenure Security in Africa, Asia and Latin America; Ubink, J.M., Hoekema, A.J., Assies, W.J., Eds.; Leiden University Press: Leiden, The Netherlands, 2000; pp. 1-21.

51. Chigbu, U.E. The Quest for "Good Governance" of Urban Land in Sub-Saharan Africa: Insight into Windhoek, Namibia. In Land Issues for Urban Governance in Sub-Saharan Africa; Home, R., Ed.; Springer: Cham, Switzerland, 2021.

52. Muller, A.; Mbanga, E. Participatory enumerations at the national level in Namibia: The Community Land Information Programme (CLIP). Environ. Urban. 2012, 24, 67-75. [CrossRef]

53. Shack Dwellers Federation of Namibia (SDFN); Namibia Housing Action Group (NHAG). Participatory Planning for Informal Settlement Upgrading in Freedom Square, Gobabis; NHAG: Windhoek, Namibia, 2014. Available online: http://sdfn.weebly.com/ uploads/2/0/9/0/20903024/freedom_square_report_clip2.pdf (accessed on 12 March 2021).

54. Republic of Namibia. Flexible Land Tenure Regulation; Government of Namibia: Windhoek, Namibia, 2018. Available online: http:/ / cms.my.na/assets/documents/p19dmn58guram30ttun89rdrp1.pdf (accessed on 14 March 2021).

55. Muller, A.; Mabakeng, R.; Gitau, J.; Selebalo, C. Experiences in Developing Business Process for Flexible Land Tenure Act Implementation in Gobabis Namibia. Available online: https://landportal.org/node/35829 (accessed on 17 March 2021).

56. Barnes, G.; Volkmann, W.; Muller, A. Drones in Support of Upgrading Informal Settlements: Potential Application in Namibia. Coordinates, November 2015. Available online: http:/ / mycoordinates.org/drones?in?support?of?upgrading?informal?settlements? potential?application?in?namibia/ (accessed on 12 March 2021).

57. Intergovernmental Panel on Climate Change (IPCC). Summary for Policymakers. In Climate Change 2013: The Physical Science Basis. Contribution of Working Group I to the Fifth Assessment Report of the Intergovernmental Panel on Climate Change; Stocker, T.F., Qin, D., Plattner, G.-K., Tignor, M., Allen, S.K., Boschung, J., Nauels, A., Xia, Y., Bex, V., Midgley, P.M., Eds.; Cambridge University Press: Cambridge, UK; New York, NY, USA, 2013; pp. 1-30.

58. Delgado, G. Land and Housing Practices in Namibia: Cases of Access to Land Rights and Production of Housing in Windhoek, Oshakati and Gobabis; University of Cape Town: Cape Town, South Africa, 2019. Available online: http://hdl.handle.net/11427/31363 (accessed on 17 March 2021).

59. Delgado, G.; Muller, A.; Mabakeng, R.; Namupala, M. Co-producing land for housing through informal settlement upgrading: Lessons from a Namibian municipality. Environ. Urban. 2020, 32, 175-194. [CrossRef]

60. Namibia Housing Action Group (NHAG); Shack Dwellers Federation of Namibia (SDFN). July 2019-June 2020 Annual Report; Namibia Housing Action Group: Windhoek, Namibia, 2020.

61. Republic of Namibia. Land Survey Act 33 of 1993; Government of Namibia: Windhoek, Namibia, 1993.

62. Republic of Namibia. Regulations of the Land Survey Act 33 of 1993; Pubublic Legislation: Windhoek, Namibia, 2002; Volume 58, p. 1. 
63. Government of Ghana. Ghana National Spatial Development Framework 2015-2035-Space, Efficiency and Growth. Final Report; Government of Ghana: Accra, Ghana, 2015; Volume I.

64. Auziňš, A.; Chigbu, U.E. Values-led Planning Approach in Spatial Development: A Methodology. Land 2021, 10, 461. [CrossRef] 